\title{
Differential effects of whole soy extract and soy isoflavones on apoptosis in prostate cancer cells
}

\author{
Anna Hsu1 ${ }^{1}$, Tammy M Bray ${ }^{1,2}$, William G Helferich ${ }^{3}$, Daniel R Doerge ${ }^{4}$, and Emily Ho ${ }^{1,2}$ \\ ${ }^{1}$ Department of Nutrition and Exercise Sciences, 103 Milam Hall \\ ${ }^{2}$ Linus Pauling Institute, 571 Weniger Hall, Oregon State University, Corvallis, OR 97331 \\ ${ }^{3}$ Department of Food Science and Human Nutrition, University of Illinois, Urbana-Champaign, IL \\ 61801 \\ ${ }^{4}$ National Center for Toxicological Research, Jefferson, AR 72079, USA
}

\section{Abstract}

Previous studies have suggested that soy isoflavones exert anticarcinogenic effects against prostate cancer. We propose that soy extracts, containing a mixture of soy isoflavones and other bioactive components, would be a more potent chemo-preventive agent than individual soy isoflavones. We compared the apoptotic effects of whole soy extracts and individual soy isoflavones, genistein and daidzein, on prostate cancer cells. The soy extract contained 50\% w/w of total isoflavones with approximately 1:5.5:3.5 ratios of genistin, daidzin and glycitin, respectively. Benign prostate hyperplasia (BPH-1), LnCap and PC3 cells were treated with varying concentrations of soy extract, genistein or daidzein and analyzed for cell cycle alterations and induction of apoptosis. At equal concentrations $(25 \mu \mathrm{mol} / \mathrm{L})$, soy extract induced a significantly higher percentage of cells undergoing apoptosis than genistein or daidzein $(P<0.001)$. No significant changes in cell cycle arrest or apoptosis were observed in non-cancerous BPH-1 cells treated with soy extract, suggesting that the effects of soy extract may be tumor cell specific. On the contrary, both genistein and daidzein induced apoptosis in BPH-1 cells, suggesting that individual isoflavones may have cytotoxicity in non-cancerous cells. Soy extracts also increased Bax expression in PC3 cells, but no significant changes in nuclear factor $k \mathrm{~B}(\mathrm{NF} k \mathrm{~B})$ activation were detected, suggesting that the induction of apoptosis was independent of the $\mathrm{NF} \kappa \mathrm{B}$ pathway. Food products that bear a combination of active compounds may be more efficacious and safer as chemo-preventive agents than individual compounds. This 'whole-food'-based approach is significant for the development of public health recommendations for prostate cancer prevention.

\section{Keywords}

soy isoflavones; prostate cancer; apoptosis; nuclear factor kappa B

Copyright $\odot 2010$ by the Society for Experimental Biology and Medicine

Corresponding author: E Ho, 117 Milam Hall, Oregon State University, Corvallis OR 97331, USA. emily.ho@ oregonstate.edu. 


\section{Introduction}

Prostate cancer is the most common type of cancer found in American men; ${ }^{1}$ however, prostate cancer rates are considerably lower in Asian countries. Migration studies have shown that the prostate cancer rate increased considerably when Asian migrants moved to the United States. Asian migrants (a high soy and tea intake population) have a lower incidence of prostate and mammary cancers than subsequent generations of Asian Americans. ${ }^{2}$ The incidence of prostate cancer in Chinese, Japanese and Filipino men born in China, Japan and the Philippines were about half of those born in the USA. ${ }^{3}$ These observations suggest that the etiology of prostate cancer is highly influenced by environmental lifestyle factors such as diet. It has been postulated that dietary factors found in the Asian diet, such as increased soy, may contribute to the decreased prostate cancer risk. A typical soy-rich Japanese diet consists of 25-100 mg soy isoflavones/day (1 serving of traditional fermented soy food contains about $25 \mathrm{mg}$ of soy isoflavones), while the typical American diet contains about $1-3 \mathrm{mg}$ soy isoflavones/day. ${ }^{4,5}$ The circulating soy isoflavone concentrations in Japanese men are at least 10-fold higher than Caucasian men, ${ }^{6,7}$ and increased soy consumption has been associated with a lower risk of prostate cancer. ${ }^{8,9}$ Even when soy consumption is moderately high, a dose-dependent inverse relationship with soy intake and localized prostate cancer incidence has been observed in Japanese populations. ${ }^{10}$ Although soy consumption appears to contribute to a decreased risk in prostate cancer, the precise mechanisms are still unclear.

Both in vitro and in vivo studies have theorized possible protective mechanisms of soy isoflavones, such as genistein, against cancer development. ${ }^{1-13}$ Soy isoflavones, which are classified as phytoestrogens, act as both estrogen agonists and antagonists by differentially binding to estrogen receptor a or $\beta^{14,15}$ and/or altering enzymes involved in hormone metabolism. ${ }^{14-16}$ Furthermore, soy isoflavone concentrates also induce G2/M arrest and p21 expressions in androgen-independent PC3 prostate cancer cells ${ }^{17}$ and may act through hormone-independent pathways that target cell cycle or apoptotic mechanisms. For instance, genistein is a known inhibitor of protein tyrosine kinase ${ }^{18}$ and topoisomerase II, ${ }^{19}$ and upregulates p21 in various cancer cells. ${ }^{20-22}$ Genistein also inhibits nuclear factor $k \mathrm{~B}$ $(\mathrm{NF} \kappa \mathrm{B})$, a transcription factor that regulates inflammatory and cellular proliferation pathways, and subsequently induces apoptosis in breast cancer cells ${ }^{23}$ and prostate cancer cells. $^{24,25}$

Nevertheless, there are still questions as to whether using high levels of soy isoflavones in humans is feasible and safe. Previous in vitro studies have often utilized supra-physiological levels ( $\geq 10 \mu \mathrm{mol} / \mathrm{L}$ ) of genistein in their treatment regimens to elicit effects, which may not be safe in vivo. ${ }^{26,27}$ It has been suggested that acute administration of high levels of soy isoflavones may not be beneficial. ${ }^{28-30}$ In contrast, longer term treatment of these bioactive compounds at low doses, such as found in whole foods, may be a safer approach. It has been postulated that the interactions between various bioactive phytochemicals found in whole foods may work synergistically together to provide additional benefits. Conversely, these interactions may also interfere with their biological activity. ${ }^{31}$ 
The present study was undertaken to compare the effectiveness of a soy extract versus individual soy isoflavones in inhibiting prostate cancer cell growth via regulation of apoptosis, cell cycle and $\mathrm{NF} k \mathrm{~B}$ activation pathways. Soy extract and individual soy isoflavones appeared to induce differential effects in PC3, LnCap and BPH-1 cells. These findings will help establish the foundation for using soy as a chemo-preventive dietary strategy for prostate cancer.

\section{Materials and methods}

\section{Cell culture}

Benign prostate hyperplasia (BPH-1) cells were generously donated by Dr Simon Hayward (Vanderbilt University Medical Center, Nashville, TN, USA), and malignant androgenindependent prostate cancer epithelial cells (PC3) and early-stage androgen-dependent prostate cancer cells (LnCap) were obtained from America Type Culture Collection (Manassas, VA, USA). All cells were grown and maintained in RPMI 1640 with glutamine (Mediatech Inc, Manassas, VA, USA) supplemented with $1 \%$ penicillin- streptomycin (Mediatech Inc) and 5\% fetal bovine serum (Hyclone, Logan, UT, USA) for BPH-1 and $10 \%$ for PC3 and $\mathrm{LnCap}$ cells at $5 \% \mathrm{CO}_{2}$ atmosphere at $37^{\circ} \mathrm{C}$.

\section{Treatments}

Crude soy extract (AdvantaSoy ${ }^{\mathrm{TM}}$ Clear 900, Cargill, MN, USA), genistein (Sigma-Aldrich, St Louis, MO, USA) and daidzein (Sigma-Aldrich) powders were dissolved in dimethyl sulfoxide (DMSO) (Sigma-Aldrich). Control treatment consisted of DMSO at a final concentration matching the dose of treated cells and less than $0.1 \%$ of the final volume. The soy extract contains $50 \% \mathrm{w} / \mathrm{w}$ of total isoflavone content with approximate 1:5.5:3.5 ratios of genistin, daidzin and glycitin, respectively. Based on the manufacturer's analyses, soy extract also contained 5\% protein, $3 \%$ ash and $10-20 \%$ saponins. The soy extract concentration was calculated by using the proportional sum of molecular weights of soy isoflavone aglycone and glycosides in the soy extract. The treatment concentrations were calculated as the total soy isoflavone contents using the combined molecular weight. The majority of the soy isoflavones in the soy extract were confirmed to be in their conjugated, glycosylated forms (97\%) with only about $3 \%$ as free aglycones by the high-performance liquid chromatography-ultraviolet method. Previous studies have suggested that genistein exhibited its anticarcinogenic effects in prostate cancer cells. However, the dosages used in previous in vitro studies were higher than physiologically attainable levels. ${ }^{12}$ Also, genistein exhibited biphasic effects on cancer cell growth in vitro, stimulating cell growth at low concentrations (less than $10 \mu \mathrm{mol} / \mathrm{L}$ ) and inhibiting proliferation at high concentrations (more than $10 \mu \mathrm{mol} / \mathrm{L}$ ). ${ }^{11}$ To establish the effective dose range for soy isoflavones in our model system, we performed dose-response experiments where cells were treated with increasing doses (from 25 to $100 \mu \mathrm{mol} / \mathrm{L}$ ) of individual soy isoflavones (genistein or daidzein) or soy extract for 24,48 and $72 \mathrm{~h}$. 


\section{Soy isoflavone analysis}

Genistein, daidzein and equol aglycone concentrations in fresh and spent cell culture media (treated with $25 \mu \mathrm{mol} / \mathrm{L}$ soy extract, genistein or daidzein for $48 \mathrm{~h}$ ) were analyzed by LC/MS/MS as described in references. ${ }^{28,32}$

\section{Multicaspase assay}

After a 48-h treatment with soy extract, genistein or daidzein, adherent and floating cells were harvested and stained with sulforhodamine-valyl-alanyl-aspartyl-fluoromethylketone (SR-VAD-FMK), a fluorochrome-conjugated caspase inhibitor, and 7-amino-actinomycin D according to the manufacturer's instructions (Guava Technologies, Hayward, CA, USA). Cell populations were quantified using a Guava personal flow cytometer (Guava Technologies).

\section{Cell cycle}

After a 48-h treatment with soy extract, genistein or daidzein, adherent and floating cells were trypsinized and fixed in ice cold $70 \%$ ethanol at 0.5 million cells per milliliter. After incubation at $-20^{\circ} \mathrm{C}$ for $12 \mathrm{~h}$, cell pellets were resuspended in cellular DNA staining solution containing $40 \mathrm{mg} / \mathrm{mL}$ propidium iodide (Sigma-Aldrich) and $100 \mu \mathrm{g} / \mathrm{mL}$ RNase (Sigma-Aldrich). Cell cycle analysis was performed using a Guava personal flow cytometer. Histograms were constructed using MultiCycle V3.0 software.

\section{Western blot analysis}

Nuclear and cytosolic extracts from treated cells were collected using the Nuclear Extract Kit (ActiveMotif, Carlsbad, CA, USA) according to the manufacturer's instructions. Protein concentrations were determined by the Bradford method (Bio-Rad Protein Assay, Bio-Rad, Hercules, CA, USA). ${ }^{33}$ Nuclear protein levels of proapoptotic protein Bax and Bcl-2 and proteins in the $\mathrm{NF} \kappa \mathrm{B}$ pathway, including $\mathrm{p} 50, \mathrm{p} 65$ (nuclear), $\mathrm{IKK} \beta, \mathrm{I} \kappa \mathrm{B} a$ and $\mathrm{p}-\mathrm{I} \kappa \mathrm{B} a$ (cytosolic) in treated cells, were qualitatively evaluated by Western blotting using the Invitrogen NuPAGE Western blotting system (NuPAGE Novex, Invitrogen, Carlsbad, CA, USA). Cell cycle markers such as p53 (CalbioChem, San Diego, CA, USA) and cMyc were also assessed. All primary antibodies specific against the proteins of interest were purchased from Santa Cruz Biotechnology Inc (Santa Cruz, CA, USA). Ponceau S red staining and $\beta-$ actin protein levels were used as protein loading controls. Secondary antibodies were conjugated with horseradish peroxidase (Bio-Rad, Hercules, CA, USA), and proteins were detected by Western Lightning Chemiluminescence Reagent Plus (PerkinElmer Life Sciences, Boston, MA, USA) and imaged by the Alpha Innotech photodocumentation system. Quantifications and densitometry were performed using NIH Image J software.

\section{NF $x$ B enzyme-linked immunosorbent assay (ELISA)}

$\mathrm{NF} \kappa \mathrm{B}$ DNA-binding activity was assessed by using transcription factor p65 and p50 ELISA kits (ActiveMotif, Carlsbad, CA, USA). Oligonucleotides containing the $\mathrm{NF} \kappa \mathrm{B}$ consensus site $\left(5^{\prime}\right.$ GGGACTTTCC $\left.3^{\prime}\right)$ were immobilized on a 96 -well plate. The active forms of NF $k B$ in the nuclear extracts were bound to the oligonucleotides on the plate and detected 
colorimetrically by spectrophotometry at an absorbance of $450 \mathrm{~nm}$ with a reference wavelength of $655 \mathrm{~nm}$.

\section{Statistics}

Experiments were performed independently three times with triplicates for each biological sample. Data were analyzed using Graph Pad Prism V4.0. One-way analysis of variance and Dunnett's multiple comparison test were used to evaluate the statistical difference; * indicated $P<0.05$ and $* *$ indicated $P<0.01$.

\section{Results}

\section{Soy extract induced cell cycle arrest and caspase activation}

We observed an induction in cell cycle arrest and apoptosis in prostate cancer cells $48 \mathrm{~h}$ post-treatment with both individual isoflavones and soy extracts. Greater than or equal to $100 \mu \mathrm{mol} / \mathrm{L}$ genistein or daidzein was needed to induce caspase activation and cell cycle arrest in LnCap and PC3 cells (Figure 1). In contrast, $25 \mu \mathrm{mol} / \mathrm{L}$ of soy extract was able to induce caspase activation in LnCap and PC 3 cells. In androgen-independent PC 3 cells, treatment with equivalent doses of soy extract $(25 \mu \mathrm{mol} / \mathrm{L})$ increased caspase activation and significantly increased the cell population in SubG1, but not in cells treated with individual soy isoflavones (Figure 2). Similarly, androgen-dependent LnCap cells had a greater sensitivity to caspase induction with soy extracts. Interestingly, the proapoptotic effects of soy extracts were more prominent in PC3 cells than in LnCap cells, as indicated by differences in the percentage of cells undergoing apoptosis. Despite the increase in caspase activity in LnCap exposed to soy extract, there was no increase in percent cells in the subG1 phase of the cell cycle. On the contrary, soy extract increased caspase activity and percent cells undergoing apoptosis in PC-3 cells. There were no significant differences in necrotic cell populations among treatments for both the LnCap and the PC 3 cells (data not shown), suggesting that perhaps there is a delay in the LnCap cells in response to soy extracts in the transition from early apoptotic events to the DNA fragmentations that would be measured by the cell cycle analysis. No significant difference in cell cycle arrest or caspase activation was found in BPH-1 cells treated with soy extracts. However, in BPH-1 cells, $50 \mu \mathrm{mol} / \mathrm{L}$ of genistein and daidzein induced caspase activation, suggesting cytotoxicity with individual isoflavones even at lower concentrations.

\section{Soy affected BAX protein expression}

To investigate subsequent events in the apoptotic pathways in prostate cancer cells, the protein expressions of $\mathrm{Bax}, \mathrm{BcL} 2, \mathrm{cMyc}$ and $\mathrm{p} 53$ in nuclear extracts of treated cells were measured by Western blotting. Soy extract, genistein and daidzein increased Bax expression in PC3 cells (Figure 3b), but not in LnCap cells (Figure 3a). There were no significant alterations in p53, BcL2 and cMyc expression among treatment groups (data not shown).

\section{No effect of soy extract on NF $x$ B activation pathways}

$\mathrm{NF} \kappa \mathrm{B}$ is a major mediator of inflammatory responses, cell proliferation and apoptosis. Expression of $\mathrm{NF} \kappa \mathrm{B}$ and its major regulatory proteins, including $\operatorname{IKK} \beta, \mathrm{p}-\mathrm{I} \kappa \mathrm{B} a$ and $\mathrm{I} k \mathrm{~B} a$, were evaluated. Soy extract did not significantly change the translocation of p50 or p65. 
However, there was a trend for daidzein to increase the level of p50 translocation $(P=$ $0.078, t$-test) (Figure 4a). There was no significant change in $\mathrm{NF} k \mathrm{~B}$ binding activity with treatments (data not shown). There were no changes in $\mathrm{NF}_{\kappa} \mathrm{B}$ inhibitory proteins in PC3 cells or LnCap cells associated with soy extract treatment (Figure 4b), but daidzein induced higher levels of phosphorylated-I $\kappa \mathrm{B} a(\mathrm{p}-\mathrm{I} \kappa \mathrm{B} a)$ targeted for degradation. The increased degradation of $\mathrm{I} k \mathrm{~B} a$ would account for the increase in p50 observed in the daidzein group.

As indicated previously, no significant changes in apoptosis and cell cycle were observed in BPH-1 cells treated with soy extract. Similarly, there were no significant changes in the $\mathrm{NF} \kappa \mathrm{B}$ pathway with soy extract treatments observed in BPH-1 cells (data not shown). These results suggest that the anticarcinogenic and proapoptotic effects of soy may be specific to tumor cells.

\section{Discussion}

Our study is one of the first to directly compare the effects of soy extract and individual soy isoflavones in inhibiting prostate cancer cell proliferation at physiologically attainable concentrations. Results from the present study suggested that soy extract was more effective at inducing apoptosis in prostate cancer cells than individual soy isoflavones at equivalent physiological concentrations. Moreover, the antiproliferative effects of soy extract were specific to prostate cancer cells, especially late-stage prostate cancer PC3 cells. Both genistein and daidzein induced apoptosis in non-cancerous BPH-1 cells, whereas soy extracts had no effect. This indicated that the combination of compounds found in soy extracts may be a more efficacious, safe and specific strategy for prostate cancer prevention.

Physiological levels of total plasma soy isoflavones are normally between 1 and $2 \mu \mathrm{mol} /$ $\mathrm{L},{ }^{34,35}$ but higher concentrations can be achieved by the regular consumption of soy products, such as observed in Japanese men. ${ }^{5}$ This kind of typical exposure results in aglycone concentrations of $10-60 \mathrm{nmol} / \mathrm{L}$ (i.e. $1-3 \%$ of the total is aglycone). High levels of genistein and daidzein ( $\geq 100 \mu \mathrm{mol} / \mathrm{L}$ ) were required to induce antiproliferative effects in prostate cancer cells (Figure 1). This finding agreed with previous studies, which demonstrated that relatively high doses of soy isoflavones $(50-100 \mu \mathrm{mol} / \mathrm{L})$ were necessary to inhibit cell growth in breast and prostate cancer cells. ${ }^{23,24,27,36}$ Furthermore, the soy extracts used in our study contained mostly conjugated soy isoflavones. Analysis of aglycone concentrations confirmed that the parent soy extract contained very low concentrations of aglycone because it is predominantly in conjugated form (data not shown). After $48 \mathrm{~h}, \mathrm{LnCaP}$ and PC3 cells convert $<50 \%$ of soy extract isoflavones to aglycones (Table 1). Despite the low concentration of aglycones, our results showed that this limitation did not affect the potency of soy extract in inducing apoptosis in prostate cancer cells. Further, although non-cancerous BPH-1 cells were highly efficient at metabolizing isoflavone glycosides to their aglycones, there were no corresponding effects on apoptosis. Our observations agreed with previous studies that soy extracts containing predominantly glycosides are able to induce anticarcinogenic effects in cell culture studies and that soy isoflavone glycosides can be hydrolyzed and metabolized by prostate cancer cells. ${ }^{37}$ Further studies are needed to determine whether there are differences in the intracellular transport and utilization of soy isoflavones between cell lines. With current data, the formation of 
active aglycone isoflavones does not appear to be the limiting factor in the proapoptotic effects of soy extracts.

One of the mechanisms by which prostate cancer cells retain growth advantages may be through constitutive activation of the $\mathrm{NF} \kappa \mathrm{B}$ pathway. ${ }^{38} \mathrm{NF} \kappa \mathrm{B}$ modulates cellular inflammatory responses, cell proliferation, cell cycle and apoptosis. Previous studies by Davis et al. ${ }^{24}$ showed that $50 \mu \mathrm{mol} / \mathrm{L}$ genistein inhibited $\mathrm{NF} \kappa \mathrm{B}$ nuclear translocation by reducing phosphorylation of $\mathrm{I} k \mathrm{~B} a$. Our study showed that soy did not exert significant effects on $\mathrm{NF} k \mathrm{~B}$. On the contrary, daidzein appeared to slightly increase $\mathrm{p} 50$ protein expression by increasing the degradation of $\mathrm{I} k \mathrm{~B} a$ in PC 3 cells (Figure $4 a$ ). It appeared that physiological concentrations of soy isoflavones have markedly different responses in prostate cancer cells than supra-physiological ones. Physiological concentrations of soy may be more effective at the initiation and promotion stages of cancer when $\mathrm{NF} \kappa \mathrm{B}$ acts to promote chronic inflammation, rather than at later stages where $\mathrm{NF} \kappa \mathrm{B}$ is already constitutively activated and deregulated. Future in vivo chemoprevention studies that investigate the effects of soy on $\mathrm{NF} \kappa \mathrm{B}$ and inflammation in prostate carcinogenesis will have more clinical values and implications.

Soy extract induced caspase activation (Figure 2) without changes in Bax expressions in LnCap cells. On the contrary, soy extract induced caspase activation and cell cycle arrest in $\mathrm{PC} 3$ cells through Bax (Figure 3c) and independent of $\mathrm{NF}_{k} \mathrm{~B}$ activation. Soy isoflavones also exerted differential effects in LnCap and PC3 cells. In LnCap cells, soy isoflavones had no effects on caspases or Bax, but in PC3 cells, genistein and daidzein both up-regulated Bax without affecting caspase activation. A possible explanation may be that soy isoflavones regulate Bax expression, but other components of soy extract can additionally target other downstream proteins, such as the antiapoptotic caspase regulators, inhibitors of apoptosis (IAPs).$^{39}$ IAPs have been shown to protect cells from Bax-mediated mitochondrial disruption and inhibit activated caspases ${ }^{40,41}$ and prostate cancer cells, especially PC 3 and DU145 cells, over-expressed IAPs. ${ }^{42}$ The combination of up-regulated Bax and downregulated IAPs could translate into caspase activation and apoptosis observed in soy extract treatments, but not individual soy isoflavone treatments. Furthermore, previous studies indicated that decreases in the expression of caspase 3 were correlated with increased prostate cancer Gleason grade, ${ }^{43}$ and caspase 3 may be a critical factor in genistein-mediated antitumor effects in breast cancer cells. ${ }^{44}$ Therefore, identification of specific caspases and regulators of caspases in future studies will further clarify the targets of chemoprevention by soy treatments.

Soy contains several compounds in addition to isoflavones that may have anticarcinogenic effects, such as saponins and protease inhibitors. ${ }^{45-47}$ Although we did not measure the composition of these compounds in the soy extract, the Cargill manufacturer estimated the approximate content of saponins to be 10-20\% in the soy extract. The possible synergy of these other phytochemicals and their effects are an important area for future mechanistic studies. Importantly, the combinations or matrix of bio-active compounds in whole food may have greater anticancer effects than individual bioactive components. For example, dietary supplementation with whole tomato product (tomato powder) was more effective than an equal level of lycopene supplement alone in inhibiting prostate cancer growth in 
vivo. ${ }^{48}$ In soy research, a previous study has also shown that combined soy isoflavones were more efficacious than genistein or daidzein in inhibiting prostate epithelial cell growth in vitro. ${ }^{35}$ In addition, the matrix of combined soy isoflavonoids and other compounds may provide more bioactivity than individual soy isoflavonoids. For example, it has been previously shown that the other non-nutritive components present in whole soy (i.e. soy flour) modified the phase II metabolism of isoflavone aglycones in the gut or liver and that this was the proximate cause for the reduction of estrogen-dependent tumor growth. ${ }^{28}$ Following the same rationale, whether soy isoflavones interact with other components of soy and soy combines with other foods to form additional or synergistic benefits against prostate cancer cell growth will be of interest for future investigations.

In summary, soy extract was more effective in inducing cell cycle arrest and apoptosis than soy isoflavones in both early-stage (LnCap) and late-stage (PC3) prostate cancer cells. Soy extract induced cell cycle arrest at sub-G1, activated caspases and increased proapoptotic protein Bax expressions through $\mathrm{NF} k \mathrm{~B}$-independent pathways. Importantly, the proapoptotic effects of soy extract appear to be tumor cell specific. The whole-food approach (soy extract) had limited toxicity toward healthy cells while effectively inhibiting prostate cancer cell proliferation; however, future in vivo studies are needed to evaluate and compare the effects of soy and soy isoflavones on prostate cancer. Taking the whole-food approach may be more efficacious, safer and cost-effective than individual compounds for the development of evidence-based public health recommendations and a chemo-preventive strategy for prostate cancer.

\section{Acknowledgments}

This work was supported by a National Institute of Health (NIH) grant CA107693, Oregon Agriculture Experiment Station (OR00735) and the Environmental Health Science Center at Oregon State University (NIEHS P30 ES00210). Soy isoflavone HPLC measurements were done supported by P01-AG024387 to WGH and DRD from the National Institute on Aging with additional support from the National Institute for Complementary and Alternative Medicine, Office of Dietary Supplements, and the Women's Health Initiative. We are also grateful to Dr Carmen Wong for critical input in the manuscript.

\section{REFERENCES}

1. Jemal A, Siegel R, Ward E, Hao Y, Xu J, Murray T, Thun MJ. Cancer statistics, 2008. CA Cancer J Clin. 2008; 58:71-96. [PubMed: 18287387]

2. Dixon RA. Phytoestrogens. Annu Rev Plant Biol. 2004; 55:225-61. [PubMed: 15377220]

3. Cook LS, Goldoft M, Schwartz SM, Weiss NS. Incidence of adenocarcinoma of the prostate in Asian immigrants to the United States and their descendants. J Urol. 1999; 161:152-5. [PubMed: 10037388]

4. Gugger, ET. Industrial processing and preparation of isoflavones.. In: Gilani, GS.; Anderson, JB., editors. Phytoestrogens and Health. AOCS Press; Champaign, IL: 2002. p. 83-94.

5. Lamartiniere CA. Protection against breast cancer with genistein: a component of soy. Am J Clin Nutr. 2000; 71(6 Suppl):1705S-7S. discussion 1708S-9S. [PubMed: 10837323]

6. Adlercreutz H, Markkanen H, Watanabe S. Plasma concentrations of phyto-oestrogens in Japanese men. Lancet. 1993; 342:1209-10. [PubMed: 7901532]

7. Morton MS, Arisaka O, Miyake N, Morgan LD, Evans BA. Phytoestrogen concentrations in serum from Japanese men and women over forty years of age. J Nutr. 2002; 132:3168-71. [PubMed: 12368413] 
8. Yan L, Spitznagel EL. Meta-analysis of soy food and risk of prostate cancer in men. Int J Cancer. 2005; 117:667-9. [PubMed: 15945102]

9. Dalais FS, Meliala A, Wattanapenpaiboon N, Frydenberg M, Suter DA, Thomson WK, Wahlqvist ML. Effects of a diet rich in phytoestrogens on prostate-specific antigen and sex hormones in men diagnosed with prostate cancer. Urology. 2004; 64:510-5. [PubMed: 15351581]

10. Kurahashi N, Iwasaki M, Sasazuki S, Otani T, Inoue M, Tsugane S. Soy product and isoflavone consumption in relation to prostate cancer in Japanese men. Cancer Epidemiol Biomarkers Prev. 2007; 16:538-45. [PubMed: 17337648]

11. Magee PJ, Rowland IR. Phyto-oestrogens, their mechanism of action: current evidence for a role in breast and prostate cancer. Br J Nutr. 2004; 91:513-31. [PubMed: 15035679]

12. Park OJ, Surh YJ. Chemopreventive potential of epigallocatechin gallate and genistein: evidence from epidemiological and laboratory studies. Toxicol Lett. 2004; 150:43-56. [PubMed: 15068824]

13. Sarkar FH, Li Y. Soy isoflavones and cancer prevention. Cancer Invest. 2003; 21:744-57. [PubMed: 14628433]

14. Lee H, Wang HW, Su HY, Hao NJ. The structure-activity relationships of flavonoids as inhibitors of cytochrome P-450 enzymes in rat liver microsomes and the mutagenicity of 2-amino-3-methylimidazo [4,5-f]quinoline. Mutagenesis. 1994; 9:101-6. [PubMed: 8201941]

15. Makela S, Poutanen M, Kostian ML, Lehtimaki N, Strauss L, Santti R, Vihko R. Inhibition of 17beta-hydroxysteroid oxidoreductase by flavonoids in breast and prostate cancer cells. Proc Soc Exp Biol Med. 1998; 217:310-6. [PubMed: 9492340]

16. Adlercreutz H, Bannwart C, Wahala K, Makela T, Brunow G, Hase T, Arosemena PJ, Kellis JT Jr, Vickery LE. Inhibition of human aromatase by mammalian lignans and isoflavonoid phytoestrogens. J Steroid Biochem Mol Biol. 1993; 44:147-53. [PubMed: 8382517]

17. Handayani R, Rice L, Cui Y, Medrano TA, Samedi VG, Baker HV, Szabo NJ, Shiverick KT. Soy isoflavones alter expression of genes associated with cancer progression, including interleukin-8, in androgen-independent PC-3 human prostate cancer cells. J Nutr. 2006; 136:75-82. [PubMed: 16365062]

18. Akiyama T, Ishida J, Nakagawa S, Ogawara H, Watanabe S, Itoh N, Shibuya M, Fukami Y. Genistein, a specific inhibitor of tyrosine-specific protein kinases. J Biol Chem. 1987; 262:5592-5. [PubMed: 3106339]

19. Schmidt F, Knobbe CB, Frank B, Wolburg H, Weller M. The topoisomerase II inhibitor, genistein, induces G2/M arrest and apoptosis in human malignant glioma cell lines. Oncol Rep. 2008; 19:1061-6. [PubMed: 18357397]

20. Choi YH, Lee WH, Park KY, Zhang L. p53-independent induction of p21 (WAF1/CIP1), reduction of cyclin B1 and G2/M arrest by the isoflavone genistein in human prostate carcinoma cells. Jpn J Cancer Res. 2000; 91:164-73. [PubMed: 10761703]

21. Lian F, Li Y, Bhuiyan M, Sarkar FH. p53-independent apoptosis induced by genistein in lung cancer cells. Nutr Cancer. 1999; 33:125-31. [PubMed: 10368806]

22. Shao ZM, Alpaugh ML, Fontana JA, Barsky SH. Genistein inhibits proliferation similarly in estrogen receptor-positive and negative human breast carcinoma cell lines characterized by P21WAF1/CIP1 induction, G2/M arrest, and apoptosis. J Cell Biochem. 1998; 69:44-54. [PubMed: 9513045]

23. Valachovicova T, Slivova V, Bergman H, Shuherk J, Sliva D. Soy isoflavones suppress invasiveness of breast cancer cells by the inhibition of NF-kappaB/AP-1-dependent and independent pathways. Int J Oncol. 2004; 25:1389-95. [PubMed: 15492830]

24. Davis JN, Kucuk O, Sarkar FH. Genistein inhibits NF-kappa B activation in prostate cancer cells. Nutr Cancer. 1999; 35:167-74. [PubMed: 10693171]

25. Li Y, Sarkar FH. Inhibition of nuclear factor kappaB activation in PC3 cells by genistein is mediated via Akt signaling pathway. Clin Cancer Res. 2002; 8:2369-77. [PubMed: 12114442]

26. Matsukawa Y, Marui N, Sakai T, Satomi Y, Yoshida M, Matsumoto K, Nishino H, Aoike A. Genistein arrests cell cycle progression at G2-M. Cancer Res. 1993; 53:1328-31. [PubMed: 8443813] 
27. Perabo FG, Von Low EC, Ellinger J, von Rucker A, Muller SC, Bastian PJ. Soy isoflavone genistein in prevention and treatment of prostate cancer. Prostate Cancer Prostatic Dis. 2008; 11:6-12. [PubMed: 17923857]

28. Allred CD, Allred KF, Ju YH, Goeppinger TS, Doerge DR, Helferich WG. Soy processing influences growth of estrogen-dependent breast cancer tumors. Carcinogenesis. 2004; 25:1649-57. [PubMed: 15131010]

29. Messina MJ, Loprinzi CL. Soy for breast cancer survivors: a critical review of the literature. J Nutr. 2001; 131(11 Suppl.):3095S-108S. [PubMed: 11694655]

30. Murrill WB, Brown NM, Zhang JX, Manzolillo PA, Barnes S, Lamartiniere CA. Prepubertal genistein exposure suppresses mammary cancer and enhances gland differentiation in rats. Carcinogenesis. 1996; 17:1451-7. [PubMed: 8706248]

31. Lila M, Raskin I. Health-related interactions of phytochemicals. J Food Sci. 2005; 70:R20-7.

32. Allred CD, Twaddle NC, Allred KF, Goeppinger TS, Churchwell MI, Ju YH, Helferich WG, Doerge DR. Soy processing affects metabolism and disposition of dietary isoflavones in ovariectomized BALB/c mice. J Agric Food Chem. 2005; 53:8542-50. [PubMed: 16248551]

33. Bradford MM. A rapid and sensitive method for the quantitation of microgram quantities of protein utilizing the principle of protein-dye binding. Anal Biochem. 1976; 72:248-54. [PubMed: 942051]

34. Hedlund TE, Maroni PD, Ferucci PG, Dayton R, Barnes S, Jones K, Moore R, Ogden LG, Wahala K, Sackett HM, Gray KJ. Long-term dietary habits affect soy isoflavone metabolism and accumulation in prostatic fluid in Caucasian men. J Nutr. 2005; 135:1400-6. [PubMed: 15930444]

35. Hedlund TE, van Bokhoven A, Johannes WU, Nordeen SK, Ogden LG. Prostatic fluid concentrations of isoflavonoids in soy consumers are sufficient to inhibit growth of benign and malignant prostatic epithelial cells in vitro. Prostate. 2006; 66:557-66. [PubMed: 16372328]

36. Gong L, Li Y, Nedeljkovic-Kurepa A, Sarkar FH. Inactivation of NF-kappaB by genistein is mediated via Akt signaling pathway in breast cancer cells. Oncogene. 2003; 22:4702-9. [PubMed: 12879015]

37. Rice L, Handayani R, Cui Y, Medrano T, Samedi V, Baker H, Szabo NJ, Rosser CJ, Goodison S, Shiverick KT. Soy isoflavones exert differential effects on androgen responsive genes in LNCaP human prostate cancer cells. J Nutr. 2007; 137:964-72. [PubMed: 17374662]

38. Huang S, Pettaway CA, Uehara H, Bucana CD, Fidler IJ. Blockade of NF-kappaB activity in human prostate cancer cells is associated with suppression of angiogenesis, invasion, and metastasis. Oncogene. 2001; 20:4188-97. [PubMed: 11464285]

39. LaCasse EC, Mahoney DJ, Cheung HH, Plenchette S, Baird S, Korneluk RG. IAP-targeted therapies for cancer. Oncogene. 2008; 27:6252-75. [PubMed: 18931692]

40. Tamm I, Wang Y, Sausville E, Scudiero DA, Vigna N, Oltersdorf T, Reed JC. IAP-family protein survivin inhibits caspase activity and apoptosis induced by Fas (CD95), Bax, caspases, and anticancer drugs. Cancer Res. 1998; 58:5315-20. [PubMed: 9850056]

41. Watson RW, Fitzpatrick JM. Targeting apoptosis in prostate cancer: focus on caspases and inhibitors of apoptosis proteins. BJU Int. 2005; 96(Suppl. 2):30-4. [PubMed: 16359436]

42. McEleny KR, Watson RW, Coffey RN, O'Neill AJ, Fitzpatrick JM. Inhibitors of apoptosis proteins in prostate cancer cell lines. Prostate. 2002; 51:133-40. [PubMed: 11948968]

43. O'Neill AJ, Boran SA, O'Keane C, Coffey RN, Hegarty NJ, Hegarty P, Gaffney EF, Fitzpatrick $\mathrm{JM}$, Watson RW. Caspase 3 expression in benign prostatic hyperplasia and prostate carcinoma. Prostate. 2001; 47:183-8. [PubMed: 11351347]

44. Yang S, Zhou Q, Yang X. Caspase-3 status is a determinant of the differential responses to genistein between MDA-MB-231 and MCF-7 breast cancer cells. Biochim Biophys Acta. 2007; 1773:903-11. [PubMed: 17490757]

45. Fournier DB, Erdman JW Jr, Gordon GB. Soy, its components, and cancer prevention: a review of the in vitro, animal, and human data. Cancer Epidemiol Biomarkers Prev. 1998; 7:1055-65. [PubMed: 9829717]

46. Kerwin SM. Soy saponins and the anticancer effects of soybeans and soy-based foods. Curr Med Chem Anticancer Agents. 2004; 4:263-72. [PubMed: 15134504] 
47. McCormick DL, Johnson WD, Bosland MC, Lubet RA, Steele VE. Chemoprevention of rat prostate carcinogenesis by soy isoflavones and by Bowman-Birk inhibitor. Nutr Cancer. 2007; 57:184-93. [PubMed: 17571952]

48. Campbell JK, Canene-Adams K, Lindshield BL, Boileau TW, Clinton SK, Erdman JW Jr. Tomato phytochemicals and prostate cancer risk. J Nutr. 2004; 134(12 Suppl.):3486S-92S. [PubMed: 15570058] 


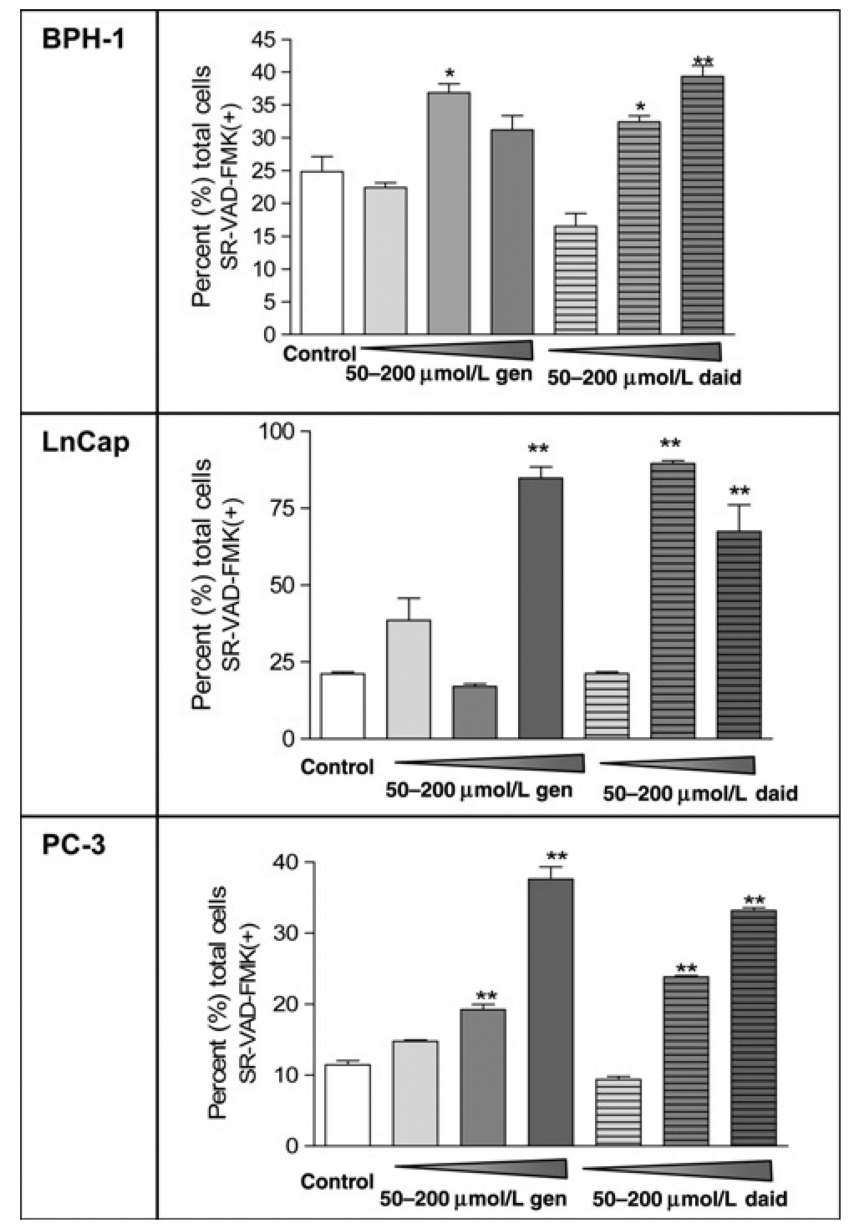

Figure 1.

High doses of genistein induced cell cycle arrest and apoptosis in benign prostate hyperplasia (BPH-1), LnCap and PC3 cells. BPH-1, LnCap and PC3 cells were treated with varying concentrations $(25,50,100$ and $200 \mu \mathrm{mol} / \mathrm{L})$ of genistein or daidzein for $48 \mathrm{~h}$, and labeled with SR-VAD-FMK stain (fluorochrome-conjugated caspase inhibitor) to assess multicaspase activity by flow cytometry. Greater than $100 \mu \mathrm{mol} / \mathrm{L}$ of genistein and daidzein induced caspase activation in LnCap and PC3 cells, but $\geq 50 \mu \mathrm{mol} / \mathrm{L}$ of genistein and daidzein also activated caspase activation in BPH-1 cells. Control treatment consisted of media with $<0.1 \%$ dimethyl sulfoxide. Values represent means $\pm \mathrm{SEM}, n=3$. $* P<0.05$, ** $P<0.01$ compared with control 


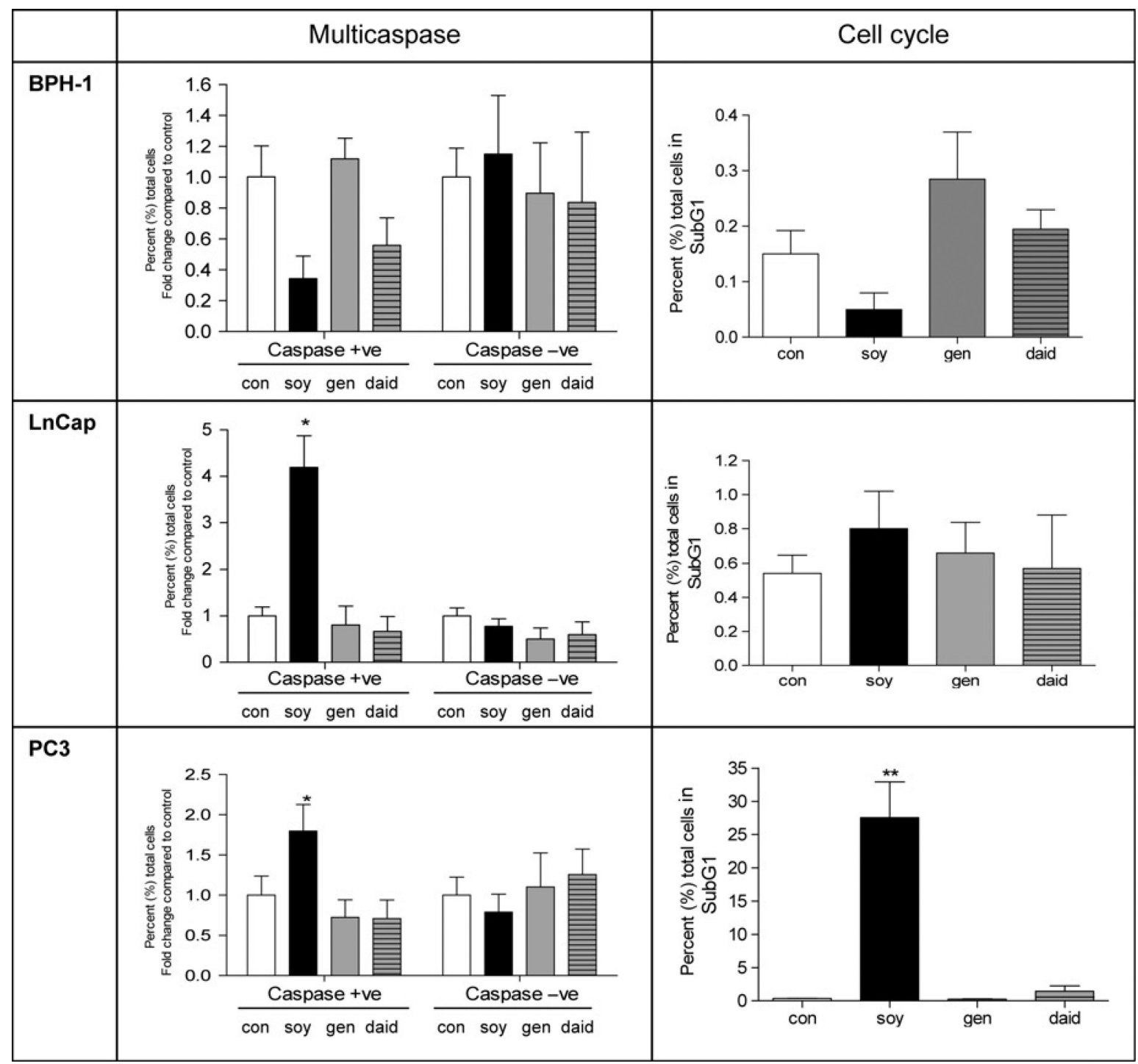

Figure 2.

$25 \mu \mathrm{mol} / \mathrm{L}$ of soy extract induced apoptosis in PC3 and LnCap cells with no effect at equal concentrations of individual soy isoflavones. Benign prostate hyperplasia (BPH-1), LnCap and PC 3 cells were treated with $25 \mu \mathrm{mol} / \mathrm{L}$ of soy extract (soy), genistein (gen) or daidzein (daid) for $48 \mathrm{~h}$. Multicaspase activity and cell cycle analysis were measured by flow cytometry. Soy extract induced higher caspase activation, indicated by more SR-VAD-FMK positively stained cells (caspase + ve cells), than genistein or daidzein at equal concentrations $(25 \mu \mathrm{mol} / \mathrm{L})$ in both LnCap and PC 3 cells. Soy extract also resulted in more cell population in the sub-G1 stage of the cell cycle in PC3 cells. No significant changes in caspase activity or cell cycle were observed in BPH-1 cells treated with soy extract or individual soy isoflavones. Control treatment consisted of media with $<0.1 \%$ dimethyl sulfoxide. Values represent means $\pm \mathrm{SEM}, n=3$. ${ }^{*} P<0.05$, $* * P<0.01$ compared with control 

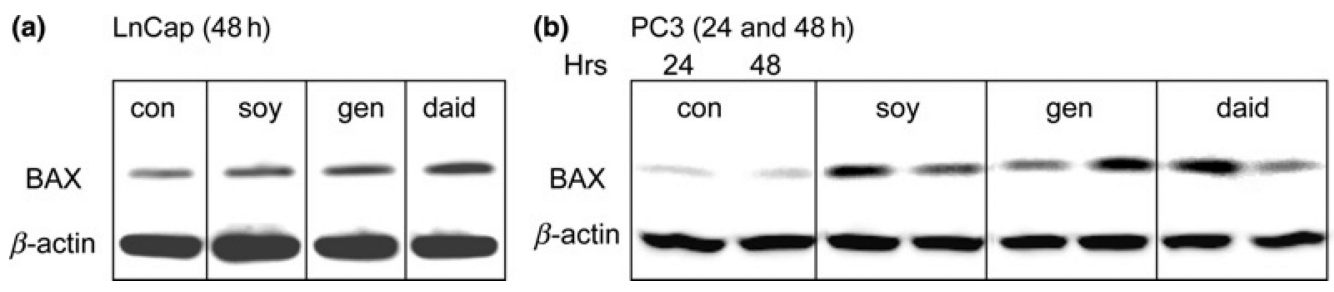

Figure 3.

Soy and soy isoflavones increased Bax expression. The protein expression levels of Bax in nuclear extracts of treated cells were measured by Western blotting. (a) LnCap and (b) PC3 cells were treated with $25 \mu \mathrm{mol} / \mathrm{L}$ of soy extract (soy), genistein (gen) or daidzein (daid). Control treatment consisted of media with $<0.1 \%$ dimethyl sulfoxide. Soy extract, genistein and daidzein increased Bax compared with control in PC3 cells, but not in LnCap cells. Representative blot of triplicate experiments 
(a)
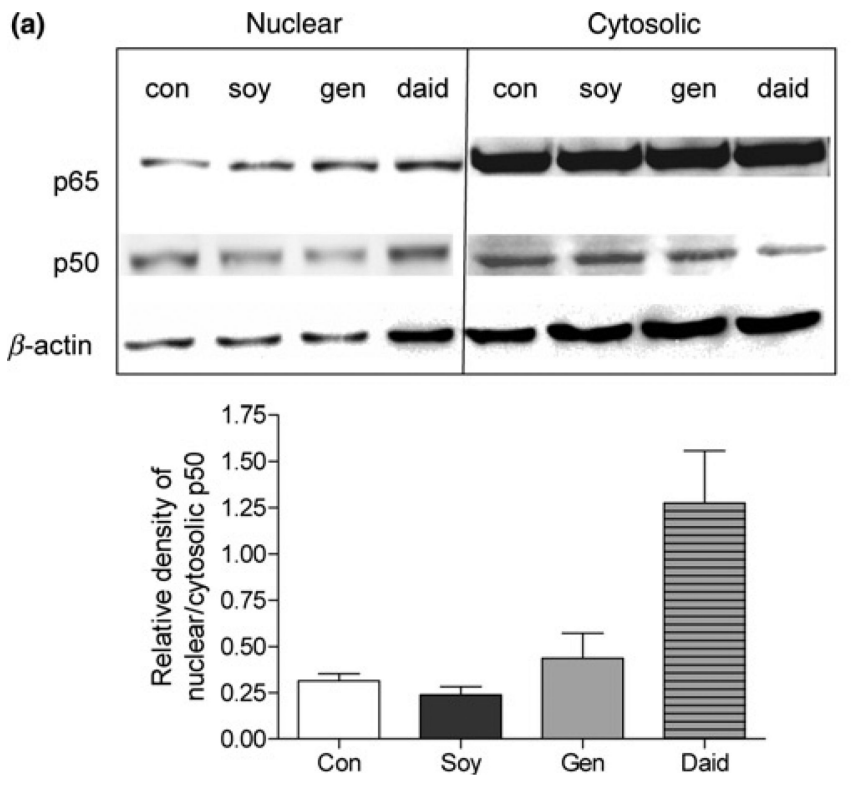

(b)
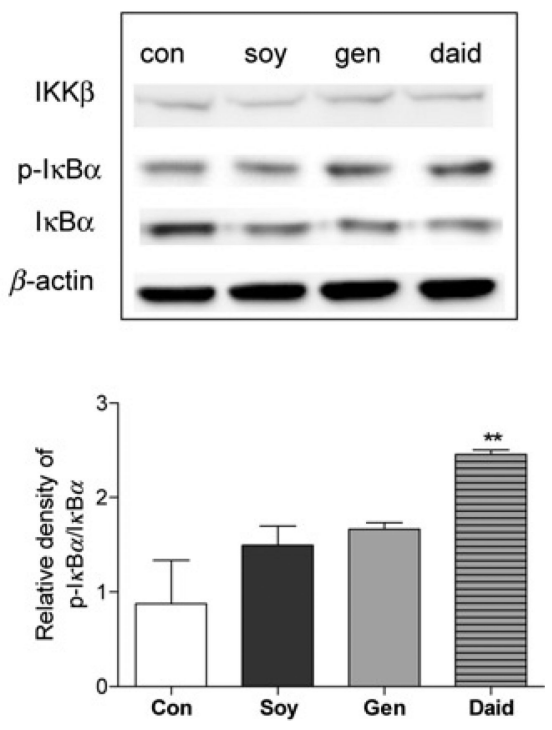

Figure 4.

No effect of soy extract on nuclear factor $k \mathrm{~B}$ activation, but an increase with daidzein treatment in PC 3 cells after $48 \mathrm{~h}$. (a) Western blots of nuclear and cytosolic extracts from PC3 cells treated with dimethyl sulfoxide (con), $25 \mu \mathrm{mol} / \mathrm{L}$ of soy extract (soy), genistein (gen) or daidzein (daid), against p50 and p65 antibodies. Relative density of nuclear/ cytosolic p50 was obtained by dividing optical density (OD) of nuclear p50 to cytosolic p50 after normalized to respective $\beta$-actin. (b) Cytosolic extract of treated PC3 cells was raised against IKK $\beta, \mathrm{p}-\mathrm{I} \kappa \mathrm{B} a$ and $\mathrm{I} k \mathrm{~B} a$. The relative density of $\mathrm{p}-\mathrm{I} \kappa \mathrm{B} \alpha / \mathrm{I} k \mathrm{~B} a$ was obtained by dividing the OD of $\mathrm{p}-\mathrm{I} k \mathrm{~B} a$ to $\mathrm{I} k \mathrm{~B} a$ and normalized to $\beta$-actin. Daidzein increased nuclear $\mathrm{p} 50$ and cytosolic $\mathrm{p}-\mathrm{I} \kappa \mathrm{B} a$ compared with control, but no significant changes were observed in cells treated with soy extract or genistein. Representative blot of triplicate experiments. Densitometry values represent means $\pm \mathrm{SEM}, n=3 . P<0.01$ compared with control 
Table 1

Soy isoflavone concentrations in treatment media of BPH-1, LnCap and PC3 cells treated with soy extract, genistein or daidzein

\begin{tabular}{|c|c|c|c|c|c|c|c|c|}
\hline Hours & \multicolumn{4}{|c|}{0} & \multicolumn{4}{|c|}{48} \\
\hline BPH-1 & ND & $0.86 \pm 0.25$ & $20.68 \pm 1.99$ & $22.21 \pm 1.86$ & $7.75 \pm 1.05^{a}$ & $22.84 \pm 2.93^{a}$ & $27.18 \pm 6.37$ & $31.12 \pm 2.56$ \\
\hline LnCap & & & & & $1.76 \pm 0.33^{b}$ & $5.41 \pm 0.70^{b}$ & $26.57 \pm 3.12$ & $31.22 \pm 2.07$ \\
\hline PC3 & & & & & $2.90 \pm 0.28^{b}$ & $6.73 \pm 0.54^{b}$ & $24.18 \pm 1.17$ & $35.50 . \pm 3.20$ \\
\hline
\end{tabular}

ND, not detectable; BPH-1, benign prostate hyperplasia

Values represent means \pm SEM, $n=3$, and units are in $\mu \mathrm{mol} / \mathrm{L}$

${ }^{a}$ Values not sharing the same superscript letter differ $P<0.05$

${ }^{b}$ Values not sharing the same superscript letter differ $P<0.05$ 